\title{
PENGARUH PEMBERIAN D-GALAKTOSA TERHADAP PERUBAHAN BERAT BADAN MENCIT JANTAN
}

\section{Indah Permata Sari ${ }^{1}$, Muhammad Ichwan ${ }^{2}$, Yahwardiah Siregar ${ }^{3}$}

1 Magister Ilmu Biomedik, Fakultas Kedokteran, Universitas Sumatera Utara, Jalan Dr. T. Mansur No.5, Padang Bulan, Kec. Medan Baru, Kota Medan, Sumatera Utara

${ }^{2}$ Departemen Farmakologi dan Terapeutik, Fakultas Kedokteran, Universitas Sumatera Utara, Jalan Dr. T. Mansur No.5, Padang Bulan, Kec. Medan Baru, Kota Medan, Sumatera Utara

${ }^{3}$ Departemen Biokimia, Fakultas Kedokteran, Universitas Sumatera Utara, Jalan Dr. T. Mansur No.5, Padang Bulan, Kec. Medan Baru, Kota Medan, Sumatera Utara e-mail :indahpermata.fisio11@gmail.com

\section{DOI : https://doi.org/10.35451/jkf.v2i2.336}

\begin{abstract}
Experimental animals are animals that are deliberately kept for animal models that are useful for learning and developing various fields of research or laboratory observation. D-galactose is used for the aging process in some experimental animals, which is an indicator of aging in experimental animals is an increase in body weight. Several previous studies have shown the administration of $D$-galactose at different doses to affect changes in body weight in experimental animals. The purpose of this study was to prove the administration of $D$-galactose increased the body weight of male mice. This research was conducted from March-July 2019, conducted at the Pharmacology Laboratory of the Faculty of Medicine, University of North Sumatra.This type of research is in-vivo experimental using post test only design. A total of 6 Swiss Webster mice were given intra-peritoneal injection of $D$-galactose $150 \mathrm{mg} / \mathrm{kg} / \mathrm{bb}$ for 6 weeks. The results of this study proved that injection of D-galactose $150 \mathrm{mg} / \mathrm{kg} / \mathrm{bb}$ intra peritoneal for 6 weeks affected the change in body weight of male mice from $31.67 \pm 1.86 \mathrm{grams}$ (before) to $35.50 \pm 1.37$ grams (after). Paired t-test showed a significant increase in body weight of male mice $(p=0.016)$. This study proves that after administration of $D$-galactose injection $150 \mathrm{mg} / \mathrm{kg} / \mathrm{bb}$ intra peritoneally for 6 weeks significantly affects the male mice weight gain.
\end{abstract}

Keywords: D-galactose, body weight, male mice

\section{PENDAHULUAN}

Hewan coba merupakan hewan yang sengaja dipelihara untuk sebagai hewan model yang bermanfaat untuk pembelajaran dan mengembangkan berbagai macam bidang ilmu dalam penelitian atau pengamatan laboratorium. Hewan yang sering 
digunakan yakni mencit (Mus musculus), tikus putih (Rattus norvegicus), kelinci, dan hamster (Tolistiawaty, et al., 2015). Hewan coba model penuaan yang diinduksi Dgalaktosa secara kronis digunakan untuk memediasi model penuaan karena pemberian D-galaktosa dapat meningkatkan stress oksidatif (Shwe et al., 2018). Ini menjadi salah satu metode yang bermanfaat untuk melakukan pengujian secara farmakologis karena hewan model penuaan yang diinduksi D-galaktosa memiliki kesamaan sistem penuaannya dengan manusia (Sulistyoningrum, 2017). Pemberian D-galaktosa dalam jumlah besar dapat menyebabkan kerusakan oksidatif pada berbagai jaringan dan organ karena, paparan sistemik terhadap D-galaktosa mempercepat proses biokimia dan morfologis penuaan termasuk sistem saraf pusat. Pada umumnya Dgalaktosa digunakan sebagai model eksperimental untuk penuaan otak (Cardoso et al., 2015). D-Galaktosa ditemukan didalam disakarida laktosa, pada produk madu, bit dan susu. Dgalaktosa adalah aldohexose yang terjadi secara alami di tubuh, termasuk di otak. Namun, ketika dosis Dgalaktosa diberikan melebihi dosis normal $(10 \mathrm{mg} / \mathrm{dL})$ dapat meningkatkan stress oksidatif yang menginduksi proses penuaan. Indikator proses penuaan salah satu ditandai dengan peningkatan berat badan mencit (Shwe et al., 2018).

Beberapa penelitian yang menggunakan D-galaktosa dengan dosis $100 / \mathrm{mg} / \mathrm{kg} / \mathrm{bb}$, diinduksi selama 6 minggu; D-galaktosa 500 $\mathrm{mg} / \mathrm{kg} / \mathrm{bb}$, diinduksi selama 6 minggu; D-galaktosa $250 \mathrm{mg} / \mathrm{kg} / \mathrm{bb}$, yang diinduksi selama 8 minggu (Parameshwaran et al., 2011; Mohammadi 2018; Kong et al., 2018)
Pada penelitian ini hewan coba yang digunakan adalah mencit karena termasuk mamalia pengerat (rodensia) yang cepat berkembang biak, mudah dipelihara dalam jumlah banyak, variasi genetik cukup banyak serta sifat anatomis dan fisiologisnya mempunyai karakteristik yang baik (Akbar Budi., 2010).

Adapun tujuan dari penelitian ini adalah untuk membuktikan pemberian D-galaktosa dengan dosis $150 \mathrm{mg} / \mathrm{kg} /$ bb selama 6 minggu meningkatkan berat badan mencit jantan.

\section{Metode}

Penelitian ini adalah penelitian eksprimental in-vivo dengan menggunakan desain post test only. Besar sampel menggunakan rumus Federer. Uji statistik yang digunakan uji $t$ berpasangan, menggunakan program SPSS versi 20. Penelitian ini dilakukan di Laboratorium Farmakologi, Fakultas Kedokteran, Universitas Sumatera Utara. Telah mendapat persetujuan komite etik tentang pelaksanaan penelitian kesehatan nomor 0363/KEPHFMIPA/2019.

Mencit diberikan injeksi Dgalaktosa $150 \mathrm{mg} / \mathrm{kg} / \mathrm{bb}$ secara intra peritoneal selama 6 minggu (Gumay et al., 2018). Sampel menggunakan mencit jantan yang berumur 8 minggu dengan berat \pm 30 gram, jumlah sampel 6 ekor mencit galur swiss webster.

Diaklimatisasi selama satu minggu sebelum diberi perlakuan, mencit dipelihara di kandang dengan temperatur sekitar $\pm 23^{\circ} \mathrm{C}$ dan kelembaban relatif $\pm 55^{\circ} \mathrm{C}$ dengan siklus 12 jam terang dan gelap, pakan higro 552 dan air minum di ad libitum selama periode perlakuan enam minggu.

Dalam penelitian ini yang dibutuhkan yaitu kandang mencit, 
kawat jaring, sarung tangan, timbangan, gelas beaker, spuit $1 \mathrm{~mL}$, masker, lampu. Bahan- bahan yang digunakan yaitu D-galaktosa (merk galactose anhydrous).

Proses kerja: Sebelum diinjeksi dengan D-galaktosa mencit terlebih dahulu ditimbang berat badannya. Setelah selesai ditimbang berat badan mencit kemudian, mencit diinjeksi dengan D-galaktosa $150 \mathrm{mg} / \mathrm{kg} / \mathrm{bb}$. D-galaktosa dilarutkan dengan aquabides sebanyak 5,25 $\mathrm{mL}$ menjadi larutan stok $2 \%$, larutan stok yang digunakan untuk injeksi mencit sebanyak 0,1 mL. Dosis D-galaktosa disesuaikan dengan berat badan awal saat ditimbang. Penimbangan berat badan mencit dilakukan satu kali dalam seminggu selama 6 minggu.

\section{Hasil}

Tabel 1 Nilai rerata berat badan mencit

\begin{tabular}{lll}
\hline & $\begin{array}{l}\text { BB (gram) } \\
\text { rata-rata } \pm \text { SD }\end{array}$ & $*$ *p \\
\cline { 1 - 2 } Sebelum & $31,67 \pm 1,86$ & \multirow{2}{*}{0,016} \\
\hline Setelah & $35,50 \pm 1,37$ & \\
\hline
\end{tabular}

Ket: Berat badan (BB)

Hasil penelitian ini menunjukkan adanya peningkatan berat badan mencit jantan. Dari uji statistik bermakna signifikan $\mathrm{p}<0,05$ $(p=0,016)$ terjadi peningkatan sebesar 3,83 gram setelah 6 minggu diinjeksi dengan D-galaktosa.

\section{PEMBAHASAN}

D-galaktosa adalah aldohexose yang terjadi secara alami di tubuh, termasuk di otak. Namun, ketika dosis D-galaktosa diberikan melebihi dosis normal $(10 \mathrm{mg} / \mathrm{dL})$ ini dapat menginduksi efek penuaan di beberapa organ yang dapat meningkatkan stress oksidatif (Shwe et al., 2018).

Pada penelitian ini pemberian Dgalaktosa menunjukkan, peningkatan berat badan mencit jantan yang sebelum diberikan 31,67 gram kemudian setelah diberikan 35,50 gram. Terjadi Peningkatan berat badan pada mencit jantan sebesar 3,83 kali setelah diinjeksi D-galaktosa disebabkan karena penumpukan lemak ditubuh yang berlebih ( Sriyanti et al., 2019).

Menurut penelitian Zhao et al., 2018 terjadi kenaikan berat badan pada mencit yang diberikan Dgalaktosa yang diberikan selama 8 minggu. Sama dengan penelitian sebelumnya Chen et al., 2019 pada mencit yang diberikan D-galaktosa sebanyak $150 \mathrm{mg} / \mathrm{kg} / \mathrm{bb}$ selama 8 minggu terjadi kenaikan berat badan.

Berbeda menurut penelitian Fatemi et al., 2018, terjadi penurunan berat badan pada mencit yang diiinduksi $D$ galaktosa dengan pemberian dosis 500 $\mathrm{mg} / \mathrm{kg} / \mathrm{bb}$, perbedaan hasil ini disebabkan karena dosis D-galaktosa yang diberikan berbeda.

Peningkatan hidrasi menyebabkan penurunan berat badan, terutama melalui penurunan makan, dan hilangnya lemak, melalui peningkatan lipolisis. Terutama pada hewan pengerat, manipulasi sistem reninangiotensin sentral atau perifer menyebabkan peningkatan respons minum dan penurunan berat badan. Ini berhubungan antara hipohidrasi kronis (dehidrasi ekstra sel) dan peningkatan kadar hormon angiotensin II (Thorhon., 2016).

\section{KESIMPULAN}

Penelitian ini membuktikan bahwa setelah diberikan injeksi D-galaktosa $150 \mathrm{mg} / \mathrm{kg} / \mathrm{bb}$ secara intra peritoneal selama 6 minggu terjadi kenaikan signifikan berat badan mencit jantan.

\section{DAFTAR PUSTAKA}

Akbar Budi, (2010), Tumbuhan dengan kandungan senyawa aktif yang berpotensi sebagai anti aperlitas. Adabia press UIN, Jakarta. 
Cardoso, A. et al. (2015). D-galactose high-dose administration failed to induce accelerated aging changes in neurogenesis, anxiety, and spatial memory on young male wistar rats, Rejuvenation Research, 18(6), pp. 497-507. doi: $10.1089 /$ rej.2015.1684.

Chen, P., Chen, F. and Zhou, B. (2019). Leonurine ameliorates Dgalactose-induced aging in mice through activation of the Nrf2 signalling pathway, 11(18). doi: 10.18632/aging. 101733

Fatemi, I. et al. (2018). Protective effect of metformin on Dgalactose-induced aging model in mice, Iranian Journal of Basic Medical Sciences, 21(1), pp. 1925.doi:

10.22038/ijbms. 2017.24331.6071

Gumay, A. R., Bakri, S. and Utomo, A. W. (2018) The Effect of Green Tea Leaf Extract on Spatial Memory Function and Superoxyde Dismutase Enzyme Activity in Mice with D-galactose Induced Dimentia, Sains Medika, 8(1),p.8.doi:

10.26532/sainsmed.v8i1.1050.

Kong, S. Z. et al. (2018) Anti-aging effect of chitosan oligosaccharide on d-galactose-induced subacute aging in mice, Marine Drugs, 16(6). doi: $10.3390 / \mathrm{md} 16060181$.

Mohammadi, E. et al. (2018). Protective effect of crocin against d-galactose-induced aging in mice., Avicenna journal of phytomedicine, 8(1), pp. 14-23.

Parameshwaran, K. et al. (2011). D Galactose Effectiveness in Modeling Aging and Therapeutic Antioxidant Treatment in Mice , Rejuvenation Research, 13(6), pp. 729-735. doi: 10.1089/rej.2010.1020.

Shwe, T. et al. (2018). Role of Dgalactose-induced brain aging and its potential used for therapeutic interventions, Experimental Gerontology. Elsevier, 101(October 2017), pp. 13-36. doi: 10.1016/j.exger.2017.10.029.
Sulistyoningrum, E. (2017). DGalactose-Induced Animal Model of Male Reproductive Aging, Jurnal Kedokteran dan Kesehatan Indonesia, 8(1), pp. 19-27. doi: 10.20885/JKKI.Vol8.Iss1.art4.

Sriyanti, S., Damayanthi, E. and Anwar, F. (2019) Status antioksidan dan oksidatif laki-laki yang mengalami kegemukan dengan pemberian minuman rosela ungu, Jurnal Gizi Indonesia, $7(2), \quad$ p. $75 . \quad$ doi: 10.14710/jgi.7.2.75-85.

Thornton, S. N. (2016). Increased Hydration Can Be Associated with Weight Loss, Frontiers in Nutrition, 3(June), pp. 1-8. doi: 10.3389/fnut.2016.00018.

Tolistiawaty, I. (2015). Gambaran Kesehatan pada Mencit (Mus musculus) di Instalasi Hewan Coba, .Jurnal Vektor Penyakit, 8(1), pp. 27-32. doi: 10.22435/vektorp.v8i1.7527.2732.

Zhao, H. et al. (2018). Antioxidant effects of compound walnut oil capsule in mice aging model induced by D-galactose, Food and Nutrition Research, 62, pp. 1-10. doi: $10.29219 /$ fnr.v62.1371. 